Research Article

\title{
Experimental Study on the Influence of Buried Geothermal Pipes on the Temperature Field of Concrete Roads
}

\author{
Yan Tan (iD, Jun Song $(\mathbb{D}$, Zhi Chen $(\mathbb{D}$, and Henglin Xiao \\ Department of Structural Engineering, School of Civil Architecture and Environment, Hubei University of Technology, \\ Wuhan 430068, China \\ Correspondence should be addressed to Henglin Xiao; xiaohenglin@hbut.edu.cn
}

Received 7 March 2021; Revised 29 April 2021; Accepted 19 May 2021; Published 27 May 2021

Academic Editor: Quantao Liu

Copyright ( 92021 Yan Tan et al. This is an open access article distributed under the Creative Commons Attribution License, which permits unrestricted use, distribution, and reproduction in any medium, provided the original work is properly cited.

Snow removal is a critical security issue for concrete roads, but geothermal methods can be an environmentally friendly and efficient alternative to traditional approaches for snow removal. In order to obtain fully the change rule of the temperature field of the concrete road under geothermal conditions, observe the relationship between temperature rise and time, and better apply the geothermal buried pipe technology to road snow and ice melting, two concrete road models with the dimension of $1 \mathrm{~m} \times 2 \mathrm{~m} \times 0.45 \mathrm{~m}$ are made. The model experiments are carried out under the conditions of $0.8 \mathrm{~m} / \mathrm{s}, 0.85 \mathrm{~m} / \mathrm{s}$, and $0.9 \mathrm{~m} / \mathrm{s}$ of pipeline flow velocity, $15 \mathrm{~cm}$ and $25 \mathrm{~cm}$ of buried pipe depth, and $10 \mathrm{~cm}$ and $15 \mathrm{~cm}$ of pipe space. The influence of flow velocity, the buried pipe depth, and space on the internal and surface temperature field of concrete road is studied. The results show that, in the flow velocity test, the temperature of the four-layer measuring points shows an upward trend under different flow velocities. With the increase of initial flow velocity, the temperature rise of the first layer measuring points gradually increases. The temperature rise value of the first layer corresponding to $0.9 \mathrm{~m} / \mathrm{s}$ is $11.66^{\circ} \mathrm{C}, 4.32^{\circ} \mathrm{C}$, and $3.13^{\circ} \mathrm{C}$ higher than $0.8 \mathrm{~m} / \mathrm{s}$ and $0.85 \mathrm{~m} / \mathrm{s}$, respectively; in the buried depth test, the first layer temperature rise at $15 \mathrm{~cm}$ is $1.85^{\circ} \mathrm{C}$ higher than that at $25 \mathrm{~cm}$; in the space test, when the buried pipe space increases from $10 \mathrm{~cm}$ to $15 \mathrm{~cm}$, the temperature rise value of the first layer decreases by $1.2^{\circ} \mathrm{C}$. From the above three influencing factors experiments, it can be obtained that the temperature rise stage of the first layer measuring points can be divided into the rapid temperature rise stage within $0-2$ hours, the temperature rise one with $2 \mathrm{~h}-6 \mathrm{~h}$, and stable temperature stage after $6 \mathrm{~h}$. Experimental observation shows that road temperature will be higher than $8^{\circ} \mathrm{C}$ within $1 \mathrm{~h}-1.2 \mathrm{~h}$, which can eliminate the road icing temperature conditions to ensure that the road does not freeze. After opening the snow melting system for $6 \mathrm{~h}$, the surface temperature of the road tends to be stable, and there is no significant change. In practical application, open the system $1.5 \mathrm{~h}$ in advance so that it can prevent road snow and freezing. After opening the system for $6 \mathrm{~h}$ or stopping snowfall and rainfall within $6 \mathrm{~h}$, close the system, and the residual temperature stored in the concrete road is used for deicing and snow melting. Ensuring that the road surface temperature is above $0^{\circ} \mathrm{C}$, the heating system is turned on intermittently to save energy. The research provides theoretical support for preventing road snow and freezing.

\section{Introduction}

Ice and snow on roads in winter can cause traffic accidents [1], and both governments and citizens have investigated snow removal in detail. Traditional deicing is considered to be "passive" snow melting [2], and common methods include manual clearing [3], mechanical clearing [4,5], and the use of snow-melting agents [6-8]. Although these methods are widely used, there are many disadvantages, such as high time consumption, high physical burden, incomplete removal, low degrees of automation, and environmental pollution [9-12]. Therefore, a novel "active" snow and ice melting method that is environmentally friendly and moderately priced and provides a high degree of automation is likely to be popular. Common "active" snow melting technology includes self-stress elastic pavement [13], lowfreezing-point pavement [14], and energy conversion pavement [15]. Self-stress elastic pavement and low-freezing-point pavement degrade in deicing performance over time [16]. Energy conversion pavement technology 
improves energy efficiency and protects the environment. Currently, energy conversion snow and ice melting pavement [17] can be divided into electrothermal and geothermal systems. The electric heating method uses external electric energy to increase the pavement temperature by converting electric energy into heat energy to melt surface snow and ice. This method can be divided into cable-heated pavement [18], conductive concrete pavement [19-21], carbon fibreheated pavement $[22,23]$, and so forth. Cable-heated pavement has a low power conversion rate, is easily damaged, and consumes considerable energy. The content of conductive concrete pavement is difficult to control, and the stability of the concrete's strength and long-term use are difficult to guarantee. Carbon fibre-heated pavement has good electrical conductivity, high strength, and good thermal stability but requires considerable energy, which is difficult to implement in mountainous areas and other areas with insufficient power supply. Therefore, a novel "active" snow and ice melting method must be developed, which has low energy consumption and is suitable for areas with insufficient power. Melting snow and ice with shallow geothermal energy can solve these problems. Gedik [24] compared the heat transfer efficiency of ammonia water and geothermal water in geothermal pipes by numerical simulations. Mahdavi et al. [25] found that a change in the temperature field has no marked effect on the effect of buried pipe angles on the temperature field of concrete roads. Mauro and Grossman [26] established a long-term dynamic simulation model to study the temperature distribution of the model, and their results showed that when the external air temperature is higher than $-4^{\circ} \mathrm{C}$, the surface temperature of the road can remain above zero throughout the winter. In recent years, universities in China have begun to study and explore the technology of geothermal snow and ice melting on roads. However, due to a long experimental research cycle and high investment costs, these results were relatively weak. $\mathrm{Xu}$ et al. [27, 28] built the first snow melting test section of solar-soil thermal-energy-coupled pavement in China and investigated the feasibility of using fluid heated pavement in cold regions of China. Wang and Zhao [29] established a small model outdoors and used geothermal energy to conduct snow melting experiments on natural snow, artificial snow, broken ice, and real ice. They concluded that a reasonable melting time and increasing the heating temperature of the fluid can effectively shorten the time to melt the snow and ice. Cui et al. [30] established a wall-soil-snow coupling model, and the mechanism of the heat melting system was analysed. The temperature field and the phase interface moving rule in the process of melting snow were obtained. The selection of system parameters (ambient conditions, diameter, burial depth, and pipeline pitch) was studied, as well. These results have important reference value for the design and optimization of heat source snow melting systems. Wang et al. [31] concluded via numerical analyses that the deicing performance of pavement increased with increasing thermal conductivity of buried pipelines, but the influence was small when the thermal conductivity was greater than 1.6. Zheng et al. [32] used a finite element method to simulate the temperature field of hot water pipelines in roads in alpine regions and concluded that the space and burial depth had a strong influence on the temperature field, while the pipe diameter had little effect. Zhang et al. [33] used shallow geothermal methods to melt snow on airport runways and created fullscale field test systems in Beijing and Harbin to perform long-term thermal stability tests. They showed that a hotpipe airport runway system is an efficient and sustainable method to melt snow and ice, has good practical applications, and can be used in central China and other countries. Numerical simulations and field tests on concrete road deicing and snow melting using geothermal energy have been widely performed. To comprehensively determine the distribution of the temperature field inside and on the surface of concrete roads, this study investigates the influence of three factors: fluid velocity, pipe burial depth, and pipe space.

The past research mainly focuses on the opening of snow melting system or the continuous opening of snow melting system after snowfall. The former will increase the time of snow melting, and the latter will waste more electrical energy. Therefore, it is necessary to study the change law of temperature inside the road under the action of geothermal and obtain the relationship between temperature rise and time, so that it guides us to open the system in advance combined with the meteorological system. By this way, the temperature conditions needed for road icing have been eliminated during snowfall, and the road will not freeze.

\section{Design and Production of Test Models}

2.1. Model Design. Based on an actual road structure, two full-scale models, $\mathrm{A}$ and $\mathrm{B}$, of concrete roads were constructed at an outdoor site. The sizes of the models were $1 \mathrm{~m} \times 2 \mathrm{~m} \times 0.45 \mathrm{~m}$. Two layers of buried pipes were arranged at depths of 15 and $25 \mathrm{~cm}$ in each model, as shown in Figure 1. To describe changes in the internal and surface temperature fields of the models, four layers of temperature sensors were arranged on the surface of the model and at depths of 15,25 , and $45 \mathrm{~cm} ; 26$ measurement points were set up in each layer. The space of the buried pipes and the arrangement of temperature measurement points in models $\mathrm{A}$ and $\mathrm{B}$ are shown in Figure 2. The detailed design parameters of models $\mathrm{A}$ and $\mathrm{B}$ are shown in Table 1 .

\section{Model Design}

The buried pipes were fixed to a wire mesh of $1 \mathrm{~m} \times 2 \mathrm{~m}$, and the mesh size was $10 \mathrm{~cm} \times 10 \mathrm{~cm}$. In addition to fixing the geothermal pipe, the wire mesh also played the role of separating the distance, which was convenient for laying the temperature measurement line. A PERT pipe with excellent toughness was used as the buried pipe, and a U-shaped layout was used to fix it on the upper portion of the primary reinforcement of the wire mesh, which was fixed by a nylon tie. Two $1 \mathrm{~m} \times 2 \mathrm{~m} \times 0.85 \mathrm{~m}$ trenches were excavated in the test site, and a $20 \mathrm{~cm}$ soil layer was filled in the base. Then, $20 \mathrm{~cm}$ of gravel was paved, compacted, and put into the mould. The insulation layer was laid for the fourth layer and 
around the mould, and a support frame was set up at the top to prevent the mould from being squeezed. An XPS extruded insulation board was used. The concrete was poured using the layered-pouring technique, and two layers of buried pipes were laid in sequence. The surface of the concrete was plastered, left to cure for 28 days, and covered with preservative film to prevent water loss. The construction process is shown in Figure 3.

\section{Test Materials and Devices}

K-type thermocouples were used and had a working temperature range between -20 and $100^{\circ} \mathrm{C}$. A JK9200 power waveform recorder was used to measure temperatures and had a working temperature range between -10 and $50^{\circ} \mathrm{C}$.

The test process for the snow and ice melting systems using the geothermal method is shown in Figure 4 and was primarily divided into four steps. First, during fluid heating, the fluid in the heat-exchanger tube went deep into the ground and exchanged heat with the fluid in the pipeline to increase the fluid temperature. Second, during system operation, the collector's valve switch was opened, the generating set was started, and the heated fluid flowed into the model. Third, during heat exchange, the temperature difference between the model and the fluid led to rapid heat exchange as the fluid flowed through the model. Then, the temperature inside and on the surface of the model increased. Last, during fluid return, the fluid temperature that had undergone heat exchange decreased, flowed out of the model, and returned to the geothermal exchange tube. The entire process then was repeated as a cycle.

\section{Experimental Design}

The model experiments are carried out under the conditions of $0.8 \mathrm{~m} / \mathrm{s}, 0.85 \mathrm{~m} / \mathrm{s}$, and $0.9 \mathrm{~m} / \mathrm{s}$ of pipeline flow velocity, $15 \mathrm{~cm}$ and $25 \mathrm{~cm}$ of buried pipe depth, and $10 \mathrm{~cm}$ and $15 \mathrm{~cm}$ of pipe space. Temperatures were recorded every half hour. Changes in the temperature fields inside and on the surface of the model within $10 \mathrm{~h}$ were measured and recorded, the temperature rise laws of the internal and surface temperature fields of the model under various working conditions were analysed, and the relationship between the temperature rise and time was summarized. A flow velocity test was performed on the first layer of model $\mathrm{A}$, and the design of the flow velocity test conditions is shown in Table 2 . The first and second layers of model A were connected, the initial flow velocity was set to $0.9 \mathrm{~m} / \mathrm{s}$, and the burial depth test was performed. The design of the burial depth test conditions is shown in Table 3. The first layer of model A and the first layer of model B were connected, the initial flow velocity was set to $0.9 \mathrm{~m} / \mathrm{s}$, and the space test was performed. The design of the space test conditions is shown in Table 4.

\section{Test Results and Discussion}

6.1. Temperature Variation and Discussion under Three Different Flow Velocities. The flow velocity determines the total amount of heat exchange per unit time of the concrete road.
The greater the flow velocity is, the greater the amount of heat exchange is. After making the concrete road model, the pressure test of the whole system was carried out. It was found that the ultimate value of the compressive stress was $3.1 \mathrm{kPa}$, and the flow velocity at this time was $1 \mathrm{~km} / \mathrm{h}$. In order to prevent the system from being always in the limit operation state, the initial circulating flow velocity was reduced slightly, and the temperature change was not obvious when the flow velocity was set too low. Therefore, the initial flow velocity was set as $0.9 \mathrm{~km} / \mathrm{h}, 0.85 \mathrm{~km} / \mathrm{h}$, and $0.8 \mathrm{~km} / \mathrm{h}$, respectively, in this paper.

Figure 5 shows the average temperature of each layer of measurement points under different upward flow trends under different flow velocities. The temperature change trend of the first three layers can be divided into a rapid heating stage (before $2 \mathrm{~h}$ ), a heating stage (2-6h), and a temperature stability stage (after $6 \mathrm{~h}$ ), and the temperature change trend of the fourth layer can be divided into a temperature rise stage (before $2 \mathrm{~h}$ ) and a stable temperature stage (after $2 \mathrm{~h}$ ). The initial temperature of the four measurement layers decreases in the following order: the fourth layer, the third layer, the second layer, and the first layer. Under the conditions of $0.8 \mathrm{~km} / \mathrm{h}$ and $0.85 \mathrm{~km} / \mathrm{h}$, the temperature of the measurement layers decreases in the following order: the second layer, the third layer, the first layer, and the fourth layer. This is because, during the velocity test, the second temperature measurement layer is the heating layer, in which the temperature rise change is the most obvious, and the third temperature measurement layer is $10 \mathrm{~cm}$ from the second layer, while the first layer is $15 \mathrm{~cm}$ from the second layer. Since this distance is far and the first layer is in direct contact with the external environment, the overall temperature of the third layer is higher than that of the first layer. Regarding the fourth layer, although the initial temperature value is the highest, it is close to the soil, and the temperature is relatively constant. Therefore, even in the temperature rise stage, the temperature rise is only about $2^{\circ} \mathrm{C}$, and thus, after heating, the temperature is lower than those of the other three layers. However, under the condition of $0.9 \mathrm{~km} / \mathrm{h}$, the temperature of the measurement layers after heating for $6 \mathrm{~h}$ decreases in the following order: the second layer, the third layer, the first layer, and the fourth layer. This shows that, under this flow velocity condition, the temperature difference between the first temperature measurement layer and the external environment temperature increases, and thus more heat energy is transferred to the surface layer, making the temperature of the first layer exceed that of the third layer after $3.5 \mathrm{~h}$.

Figure 6 shows the temperature variation of each measurement point under different flow velocities. Figure 6(a) shows that the average initial surface temperatures are $4.23,4.29$, and $4.31^{\circ} \mathrm{C}$ under the conditions of 0.8 , 0.85 , and $0.9 \mathrm{~m} / \mathrm{s}$ before heating, respectively. Under the condition of $0.8 \mathrm{~m} / \mathrm{s}$, the temperature is $9.76^{\circ} \mathrm{C}$ for $2 \mathrm{~h}$ and is stable at about $11.57^{\circ} \mathrm{C}$ after $6 \mathrm{~h}$, and, throughout the temperature rise test, the temperature value increased by $7.34^{\circ} \mathrm{C}$. Under the condition of $0.85 \mathrm{~m} / \mathrm{s}$, the temperature is $10.57^{\circ} \mathrm{C}$ for $2 \mathrm{~h}$ and is stable at about $12.82^{\circ} \mathrm{C}$ after $6 \mathrm{~h}$, and, throughout the temperature rise test, the temperature value 


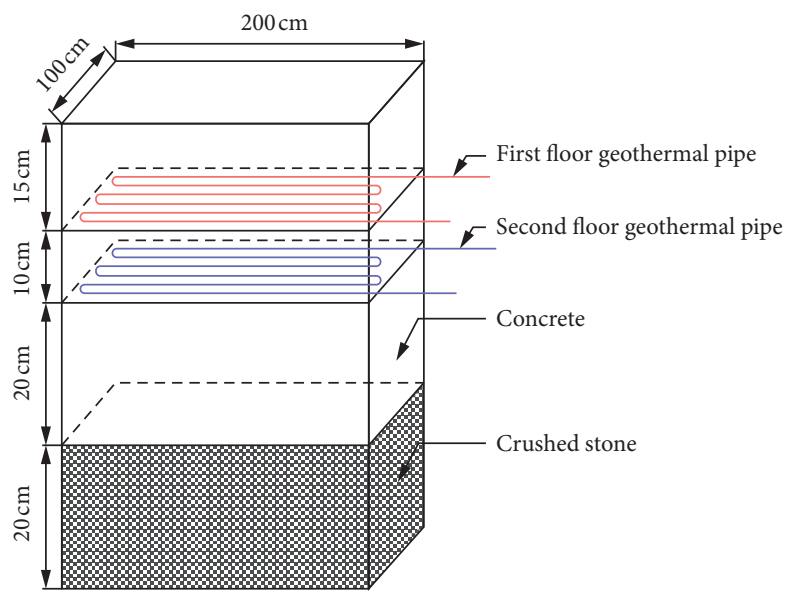

FIGURE 1: Concrete road model and buried depth design of geothermal pipes.
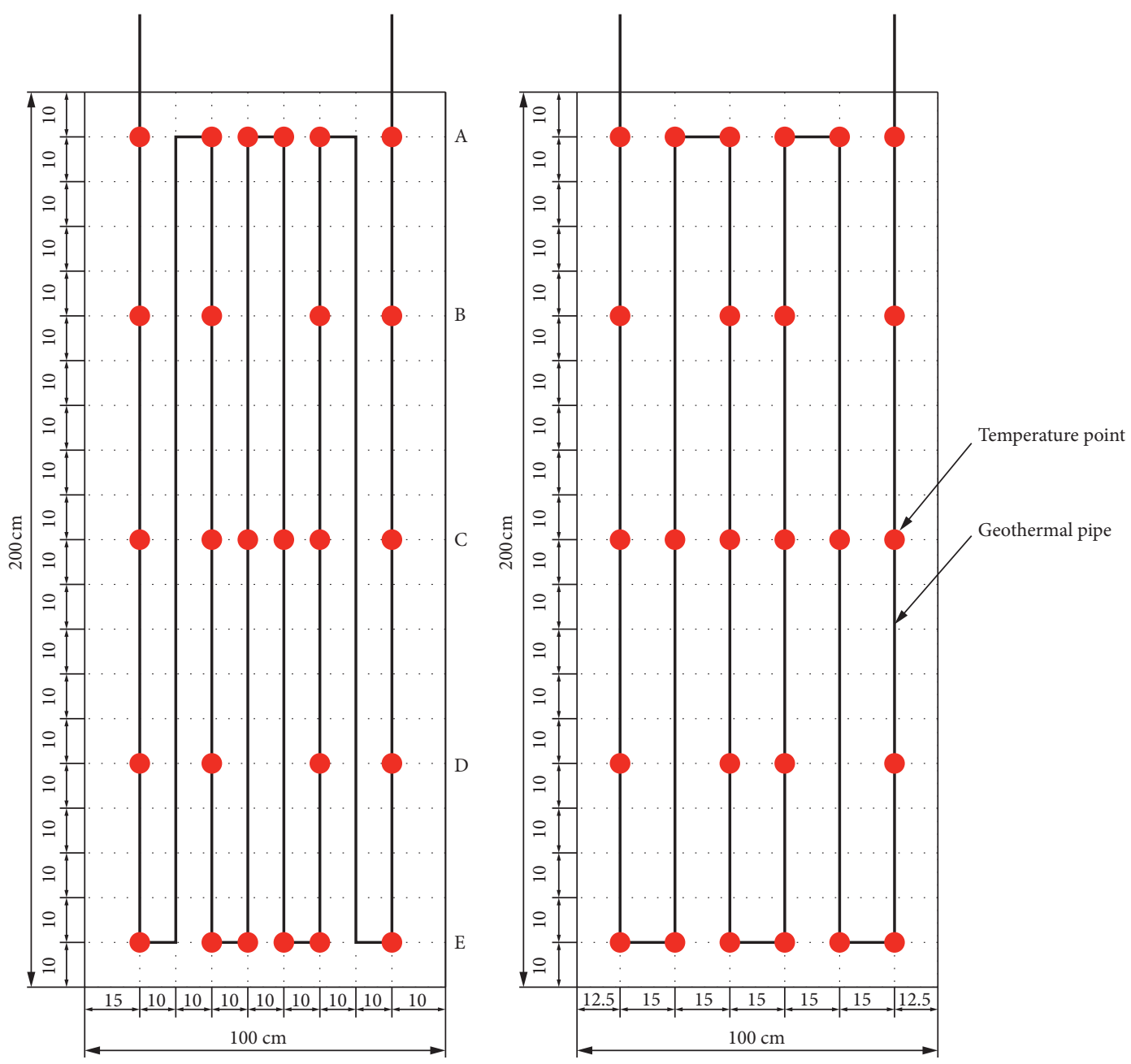

FIGURE 2: Geothermal pipe space and measurement points layout.

increased by $8.53^{\circ} \mathrm{C}$. Under the condition of $0.9 \mathrm{~m} / \mathrm{s}$, the temperature is $11.97^{\circ} \mathrm{C}$ for $2 \mathrm{~h}$ and is stable at about $15.97^{\circ} \mathrm{C}$ after $6 \mathrm{~h}$, and, throughout the temperature rise test, the temperature value increased by $11.66^{\circ} \mathrm{C}$.
These results, combined with those in Table 5, suggest that, after heating for $2 \mathrm{~h}$, the temperature rise at $0.9 \mathrm{~m} / \mathrm{s}$, $11.97^{\circ} \mathrm{C}$, is the highest, $2.21^{\circ} \mathrm{C}$ higher than that at $0.8 \mathrm{~m} / \mathrm{s}$ and $1.4^{\circ} \mathrm{C}$ higher than that at $0.85 \mathrm{~m} / \mathrm{s}$. After heating for $6 \mathrm{~h}$, the 
TABle 1: Detailed model design parameters.

Model number Model scale $(\mathrm{m})$ Buried pipe space $(\mathrm{cm})$ Pipe buried depth $(\mathrm{cm})$ Depth of the temperature measurement line $(\mathrm{cm})$ A 10

B

$1 \times 2 \times 0.45$

10

15 The first layer (0)

The second layer $(15 \mathrm{~cm})$

The third layer $(25 \mathrm{~cm})$

The fourth layer $(45 \mathrm{~cm})$

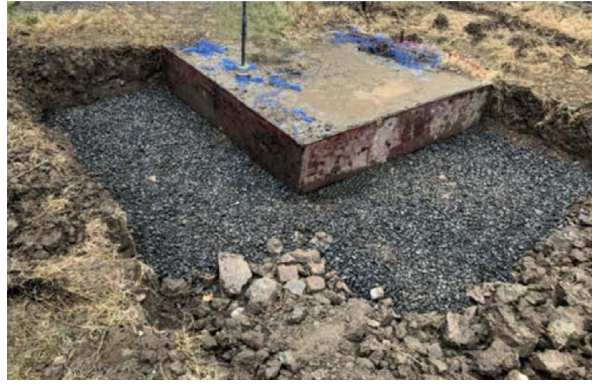

(a)

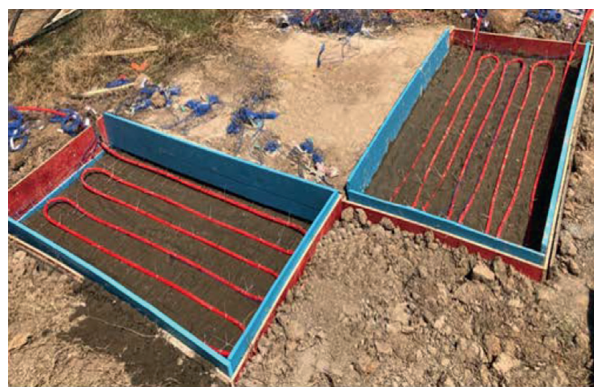

(c)

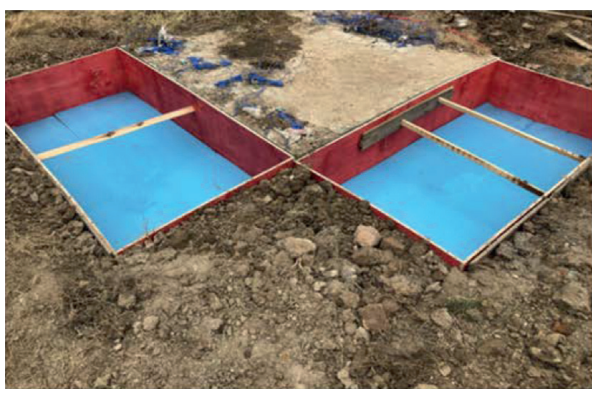

(b)

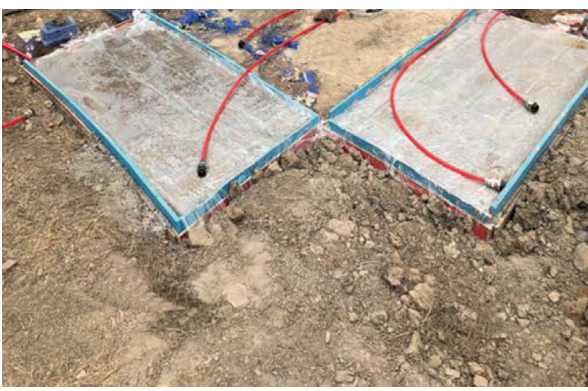

(d)

Figure 3: Construction flow chart. (a) Macadam laying. (b) Support mould. (c) Geothermal pipe laying. (d) Concrete curing.

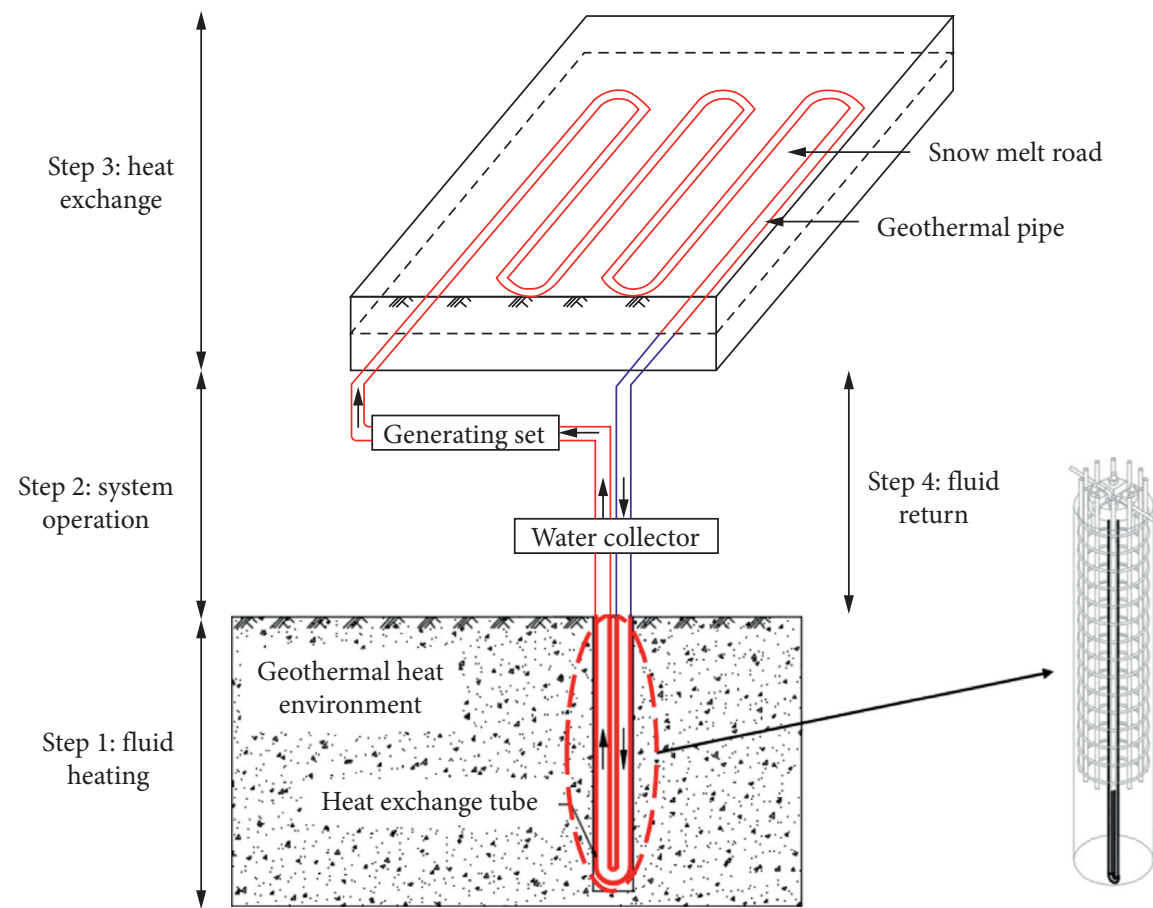

FIgURE 4: Flow chart of the model test. 
TABLE 2: Design of flow velocity working conditions.

\begin{tabular}{lcc}
\hline Initial circulating water flow velocity $(\mathrm{m} / \mathrm{s})$ & Pipe buried depth $(\mathrm{cm})$ & Buried pipe space $(\mathrm{cm})$ \\
\hline 0.8 & 15 & 10 \\
0.85 & & 10 \\
0.9 & & \\
\hline
\end{tabular}

TABle 3: Design of buried depth working conditions.

\begin{tabular}{lcc}
\hline Pipe burial depth $(\mathrm{cm})$ & Initial circulating water flow velocity $(\mathrm{m} / \mathrm{s})$ & Buried pipe space $(\mathrm{cm})$ \\
\hline 15 & 0.9 & 10 \\
25 & & 10 \\
\hline
\end{tabular}

TABle 4: Design of space working conditions.

\begin{tabular}{lcc}
\hline Buried pipe space $(\mathrm{cm})$ & Initial circulating water flow velocity $(\mathrm{m} / \mathrm{s})$ & Pipe burial depth $(\mathrm{cm})$ \\
\hline 10 & 0.9 & 15 \\
15 & & \\
\hline
\end{tabular}
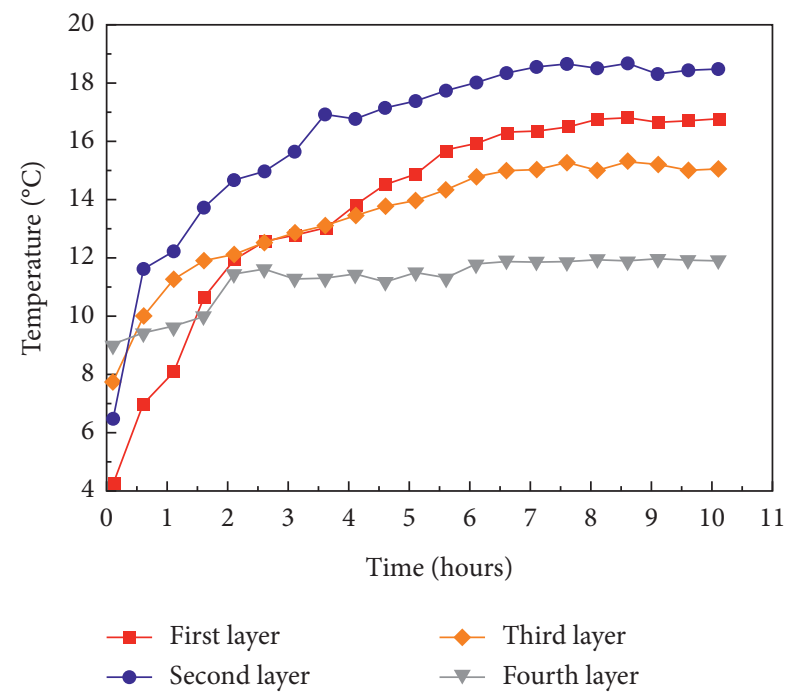

(a)
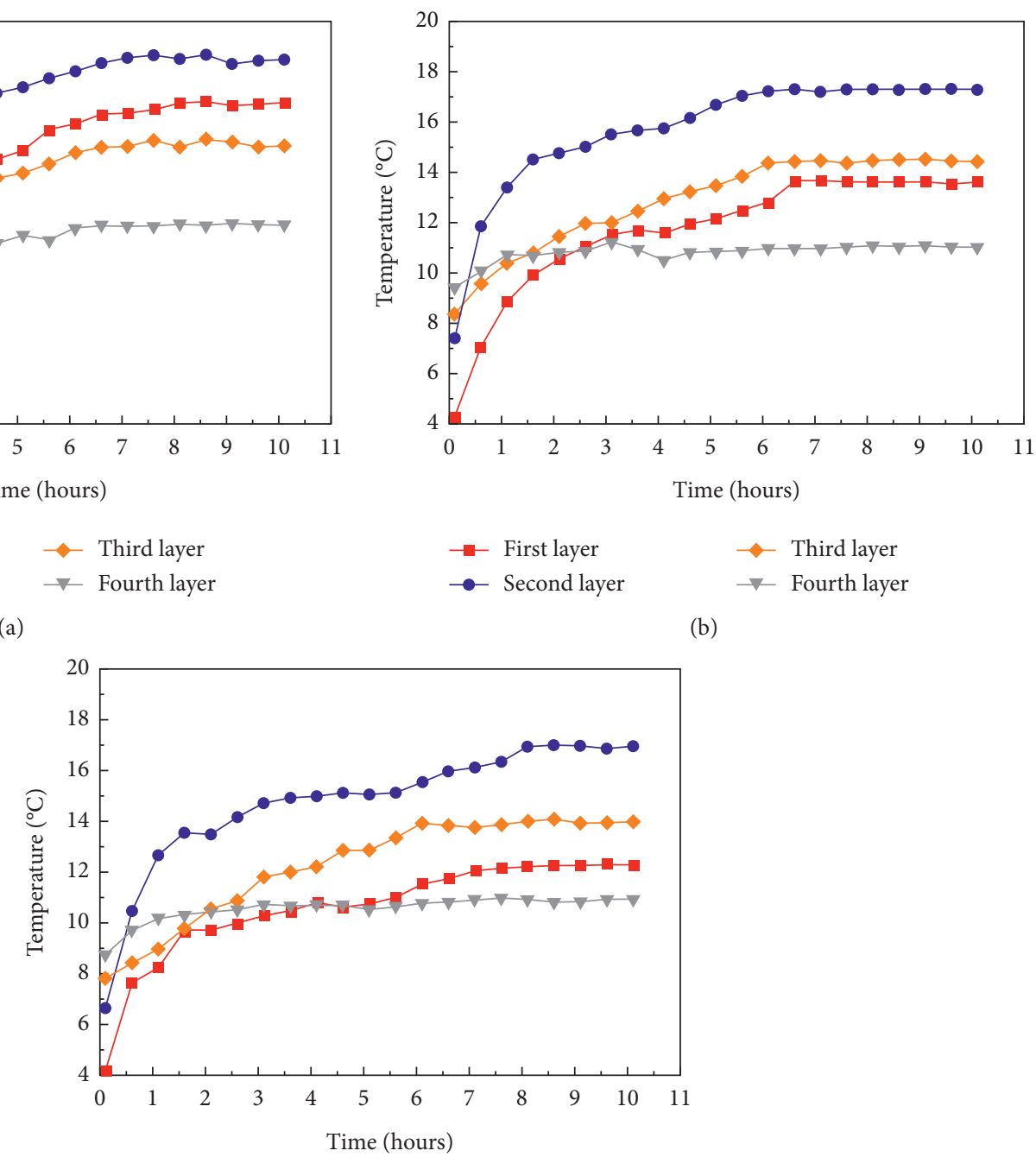

(b)

$$
\begin{aligned}
& \rightarrow \text { Third layer } \\
& \rightarrow \text { Fourth layer }
\end{aligned}
$$

$$
\begin{array}{lll}
\rightarrow-\text { First layer } & \checkmark \text { Third layer } \\
\rightarrow \text { Second layer } & \rightarrow & \text { Fourth layer }
\end{array}
$$

(c)

Figure 5: Temperature change curves of the measuring points of four layers under different flow velocities: (a) $0.8 \mathrm{~m} / \mathrm{s}$; (b) $0.85 \mathrm{~m} / \mathrm{s}$; (c) $0.9 \mathrm{~m} / \mathrm{s}$. 
temperature rise at $0.9 \mathrm{~m} / \mathrm{s}$ is $4.4^{\circ} \mathrm{C}$ higher than that at $0.8 \mathrm{~m} /$ $\mathrm{s}$ and $3.15^{\circ} \mathrm{C}$ higher than that at $0.85 \mathrm{~m} / \mathrm{s}$. Upon comprehensive analysis of the temperature rise from the initial value to the stable stage, the temperature rise is $11.66^{\circ} \mathrm{C}$ at $0.9 \mathrm{~m} / \mathrm{s}$, which is $4.32^{\circ} \mathrm{C}$ and $3.13^{\circ} \mathrm{C}$ higher than those at $0.8 \mathrm{~m} / \mathrm{s}$ and $0.85 \mathrm{~m} / \mathrm{s}$, respectively. Clearly, increasing the initial velocity value can improve the first layer temperature rise when the burial depth of the geothermal pipe is $15 \mathrm{~cm}$ and the buried pipe space is $10 \mathrm{~cm}$.

According to the existing research [34], when the pavement temperature is $0-4^{\circ} \mathrm{C}$, the ice-water mixture on the road easily freezes. To ensure that road icing does not occur, road icing temperature conditions must be eliminated. The above conditions can be satisfied when the test temperature is higher than $8^{\circ} \mathrm{C}$. Figure $6(\mathrm{a})$ shows that the road temperature can exceed $8^{\circ} \mathrm{C}$ after about $1 \mathrm{~h}$.

Table 6 shows the temperature rise test results of the second layer, third layer, and fourth layer under three flow velocity conditions. Combined with Figure 6(b), the temperature change law of the second layer of the flow velocity test shows that, before heating, the average initial temperatures at $0.8,0.85$, and $0.9 \mathrm{~m} / \mathrm{s}$ are $6.67,7.43$, and $6.49^{\circ} \mathrm{C}$, respectively. After heating for $2 \mathrm{~h}$, the temperatures are $13.51^{\circ} \mathrm{C}, 14.76^{\circ} \mathrm{C}$, and $14.67^{\circ} \mathrm{C}$. After heating for $6 \mathrm{~h}$, the temperatures are $15.55^{\circ} \mathrm{C}, 17.23^{\circ} \mathrm{C}$, and $18.03^{\circ} \mathrm{C}$. Compared with the initial temperature, the temperature increases after temperature stabilization are $8.88^{\circ} \mathrm{C}, 9.8^{\circ} \mathrm{C}$, and $11.54^{\circ} \mathrm{C}$. The temperature rise at $0.9 \mathrm{~m} / \mathrm{s}$ is $2.66^{\circ} \mathrm{C}$ and $1.74^{\circ} \mathrm{C}$ higher than those at $0.8 \mathrm{~m} / \mathrm{s}$ and $0.85 \mathrm{~m} / \mathrm{s}$, respectively. Figure $6(\mathrm{c})$ shows the temperature variation of the third layer of the flow velocity test. Before heating, the average initial temperatures at $0.8,0.85$, and $0.9 \mathrm{~m} / \mathrm{s}$ are $7.84,8.39$, and $7.76^{\circ} \mathrm{C}$, respectively. After heating for $2 \mathrm{~h}$, the temperatures are $10.58^{\circ} \mathrm{C}$, $11.47^{\circ} \mathrm{C}$, and $12.12^{\circ} \mathrm{C}$. After heating for $6 \mathrm{~h}$, the temperatures are $13.93^{\circ} \mathrm{C}, 14.89^{\circ} \mathrm{C}$, and $14.79^{\circ} \mathrm{C}$. Compared with the initial temperature, the temperature increases after temperature stabilization are $6.09^{\circ} \mathrm{C}, 6.5^{\circ} \mathrm{C}$, and $7.03^{\circ} \mathrm{C}$. The temperature rise of $0.9 \mathrm{~m} / \mathrm{s}$ is $0.94^{\circ} \mathrm{C}$ and $0.53^{\circ} \mathrm{C}$ higher than those of $0.8 \mathrm{~m} / \mathrm{s}$ and $0.85 \mathrm{~m} / \mathrm{s}$, respectively. Figure $6(\mathrm{~d})$ shows the temperature variation of the fourth layer during the velocity test. Before heating, the average initial temperatures of $0.8 \mathrm{~m} / \mathrm{s}, 0.85 \mathrm{~m} / \mathrm{s}$, and $0.9 \mathrm{~m} / \mathrm{s}$ are $8.78^{\circ} \mathrm{C}, 9.45^{\circ} \mathrm{C}$, and $9.05^{\circ} \mathrm{C}$, respectively. After heating for $2 \mathrm{~h}$, the temperatures are $10.48^{\circ} \mathrm{C}, 10.83^{\circ} \mathrm{C}$, and $11.45^{\circ} \mathrm{C}$. According to the previous analysis, after heating for $2 \mathrm{~h}$, the temperature of the fourth layer tends to be stable. Compared with the initial temperature, the temperature increases after temperature stabilization are $1.7^{\circ} \mathrm{C}, 1.38^{\circ} \mathrm{C}$, and $2.4^{\circ} \mathrm{C}$. There is no obvious law between the temperature rises under the three conditions, which may be because the fourth temperature measurement layer is relatively stable in the soil environment, and the road temperature has little effect on it.

\subsection{Temperature Variation and Discussion under Different} Buried Depth Conditions. The pipeline depth is the vertical distance between the top of the pipeline and the pavement surface, which determines the heat loss of concrete roads. For the same concrete road, a shallow pipe yields less heat loss, and thus more heat is stored within the pavement surface. We set a flow velocity of $0.9 \mathrm{~m} / \mathrm{s}$ and pipe spaces of 10,15 , and $25 \mathrm{~cm}$ at two different burial depths to investigate how the temperatures vary. Figure 7 shows the temperature variation of the four measurement layers under different buried depths.

Figure 7 shows that the average temperature of each layer of measurement points under different burial depths shows an overall upward trend. The temperature variation of the four measurement layers under the condition of $15 \mathrm{~cm}$ is shown in Figure 7(a). The initial temperature of the four measurement layers decreases in the following order: the fourth layer, the third layer, the second layer, and the first layer. After heating for $6 \mathrm{~h}$, the temperature of the four measurement layers is sorted as follows: the second layer, the first layer, the third layer, and the fourth layer. The temperature variation of the four measurement layers under the condition of $25 \mathrm{~cm}$ is shown in Figure 7(b). The initial temperature of the four measurement layers decreases in the following order: the fourth layer, the third layer, the second layer, and the first layer. After heating for $6 \mathrm{~h}$, the temperature of the four measurement layers decreases in the following order: the third layer, the second layer, the first layer, and the fourth layer. The test results show that, with the increase in the burial depth, the temperature rise of the first layer and the second layer decreases, and the temperature rise of the third layer and the fourth layer increases. Therefore, reducing the burial depth of the geothermal pipe can increase the temperature rise of the first layer. According to Table 7, before heating, the average initial temperatures of the first layer at $15 \mathrm{~cm}$ and $25 \mathrm{~cm}$ are $4.31^{\circ} \mathrm{C}$ and $4.32^{\circ} \mathrm{C}$, respectively. After heating for $2 \mathrm{~h}$, the temperatures of the two conditions are $11.97^{\circ} \mathrm{C}$ and $10.14^{\circ} \mathrm{C}$. After heating for $6 \mathrm{~h}$, the temperatures are $15.97^{\circ} \mathrm{C}$ and $14.13^{\circ} \mathrm{C}$, respectively. Compared with the initial temperature, the increased temperatures are $11.66^{\circ} \mathrm{C}$ and $9.81^{\circ} \mathrm{C}$, respectively. The first layer temperature at $15 \mathrm{~cm}$ is $1.85^{\circ} \mathrm{C}$ higher than that at $25 \mathrm{~cm}$. When the initial flow velocity is set to $0.9 \mathrm{~m} / \mathrm{s}$ and the buried pipe space is set to $10 \mathrm{~cm}$, reducing the burial depth of the pipe can improve the temperature rise of the first layer. Analysis of the relationship between the first layer temperature rise and time in Figure 7 shows that, after about $1.2 \mathrm{~h}$, the pavement temperature exceeds $8^{\circ} \mathrm{C}$.

The second layer temperature variation in the burial depth test can be analysed with Table 8 . Before heating, the average initial temperatures with pipes at 15 and $25 \mathrm{~cm}$ are 6.49 and $6.47^{\circ} \mathrm{C}$, respectively. After heating for $2 \mathrm{~h}$, the temperatures of the two conditions are $14.67^{\circ} \mathrm{C}$ and $13.72^{\circ} \mathrm{C}$. After heating for $6 \mathrm{~h}$, the temperatures are $18.03^{\circ} \mathrm{C}$ and $17.11^{\circ} \mathrm{C}$, respectively. Compared with the initial temperature, the temperature rises are $11.54^{\circ} \mathrm{C}$ and $10.64^{\circ} \mathrm{C}$, respectively. The second layer temperature at $15 \mathrm{~cm}$ is $0.9^{\circ} \mathrm{C}$ higher than that at $25 \mathrm{~cm}$. Table 8 is used to analyse the temperature variation in the third layer of the burial depth test. Before heating, the average initial temperatures with pipes at 15 and $25 \mathrm{~cm}$ are 7.76 and $7.81^{\circ} \mathrm{C}$, respectively. Figure 7 shows that the fourth layer temperatures in the burial depth test with pipes at 15 and $25 \mathrm{~cm}$ are 9.05 and $9.15^{\circ} \mathrm{C}$ initially, respectively. After heating for $2 \mathrm{~h}$, the 

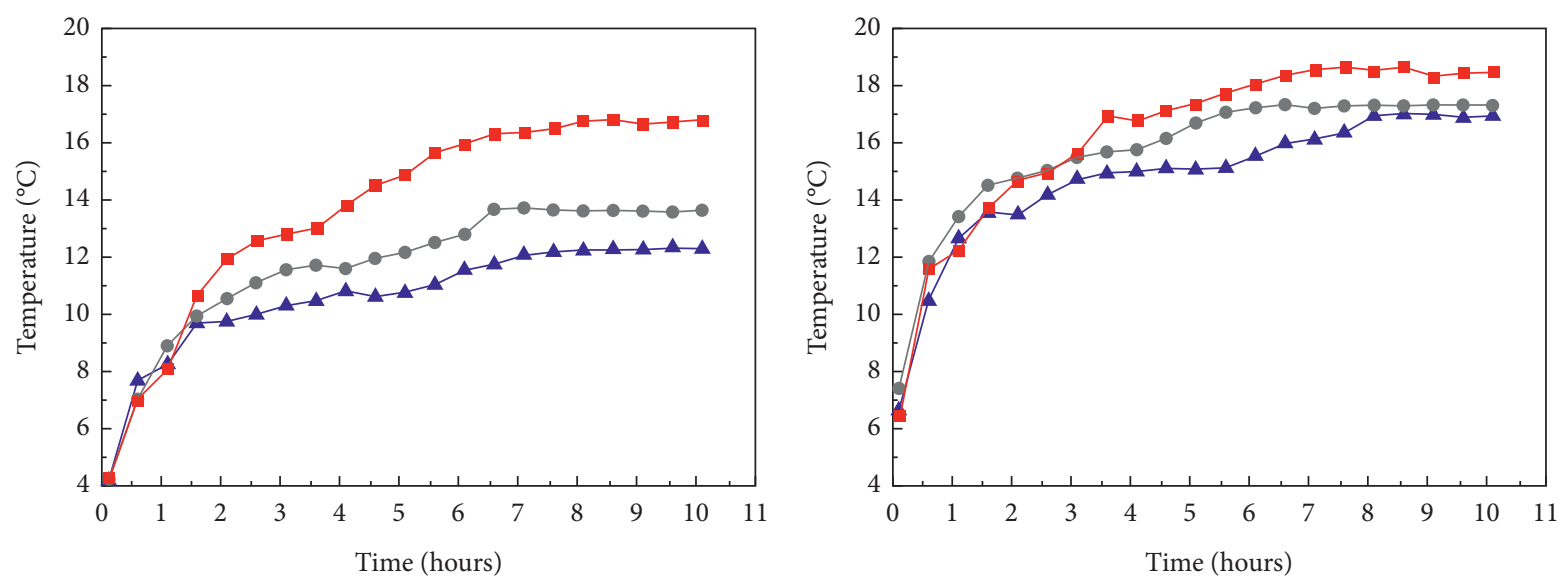

$\neg$ Velocity value $0.8 \mathrm{~m} / \mathrm{s}$

$\longrightarrow$ Velocity value $0.85 \mathrm{~m} / \mathrm{s}$

$\rightarrow$ Velocity value $0.9 \mathrm{~m} / \mathrm{s}$

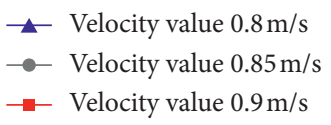

(a)

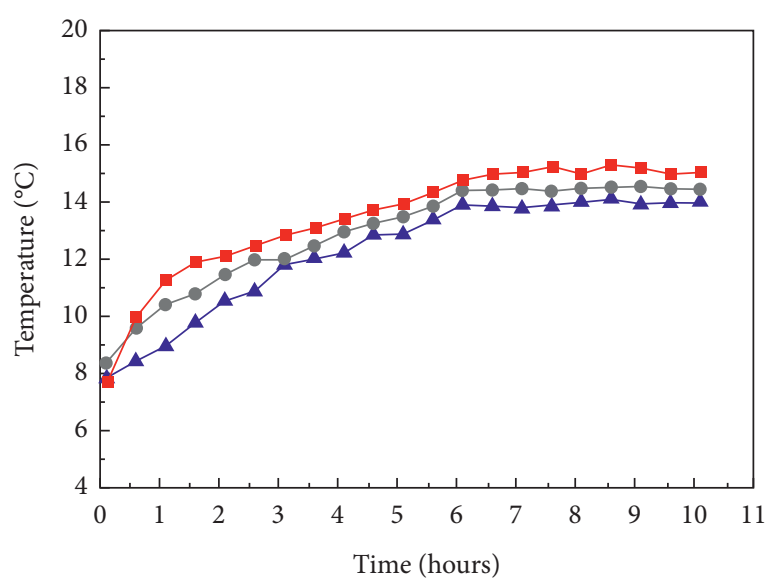

(b)

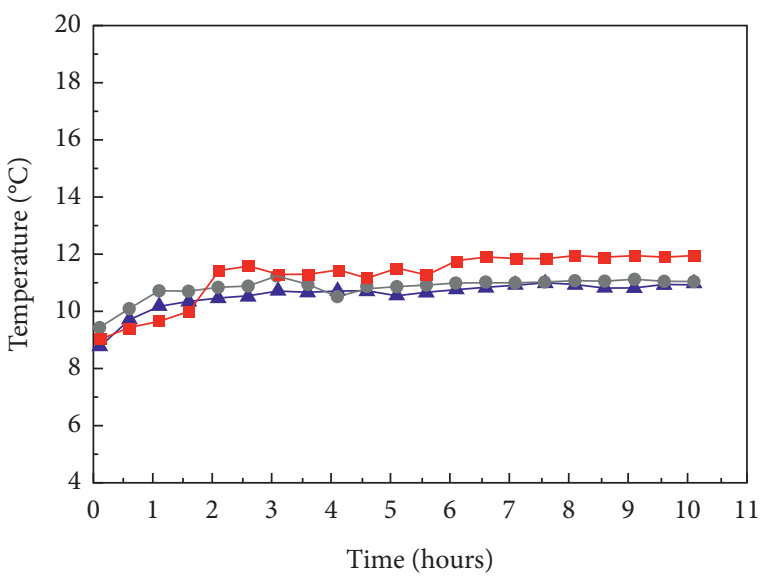

$\multimap$ Velocity value $0.8 \mathrm{~m} / \mathrm{s}$
$\rightarrow-$ Velocity value $0.85 \mathrm{~m} / \mathrm{s}$
$\rightarrow-$ Velocity value $0.9 \mathrm{~m} / \mathrm{s}$

$\multimap$ Velocity value $0.8 \mathrm{~m} / \mathrm{s}$
$\multimap$ Velocity value $0.85 \mathrm{~m} / \mathrm{s}$
$\rightarrow$ Velocity value $0.9 \mathrm{~m} / \mathrm{s}$

(d)

FIGURE 6: Temperature change curves of the measuring points of each layer: (a) the first layer; (b) the second layer; (c) the third layer; (d) the fourth layer.

TABLE 5: Temperature rise value of the first layer under flow velocity conditions.

\begin{tabular}{lcccc}
\hline $\begin{array}{l}\text { Flow velocity } \\
(\mathrm{m} / \mathrm{s})\end{array}$ & $\begin{array}{c}\text { Initial temperature } \\
\left({ }^{\circ} \mathrm{C}\right)\end{array}$ & $\begin{array}{c}\text { Temperature after } \\
2 \mathrm{~h}\left({ }^{\circ} \mathrm{C}\right)\end{array}$ & $\begin{array}{c}\text { Temperature after } \\
6 \mathrm{~h}\left({ }^{\circ} \mathrm{C}\right)\end{array}$ & $\begin{array}{c}\text { The temperature rise value between initial temperature } \\
\text { and temperature after } 6 \mathrm{~h}\left({ }^{\circ} \mathrm{C}\right)\end{array}$ \\
\hline 0.8 & $5.23^{\circ} \mathrm{C}$ & 9.76 & 11.57 & 6.34 \\
0.85 & $6.19^{\circ} \mathrm{C}$ & 10.57 & 12.82 & 6.63 \\
0.9 & $4.31^{\circ} \mathrm{C}$ & 11.97 & 15.97 & 11.66 \\
\hline
\end{tabular}

temperatures are $12.12^{\circ} \mathrm{C}$ and $14.33^{\circ} \mathrm{C}$. After heating for $6 \mathrm{~h}$, the temperatures are $14.79^{\circ} \mathrm{C}$ and $17.73^{\circ} \mathrm{C}$, respectively. Compared with the initial temperature, the temperature rises are $7.03^{\circ} \mathrm{C}$ and $9.52^{\circ} \mathrm{C}$, respectively. The first layer temperature rise under the $15 \mathrm{~cm}$ condition is $2.49^{\circ} \mathrm{C}$ lower than that under the $25 \mathrm{~cm}$ condition. In the burial depth test, because the heating layer changes from $15 \mathrm{~cm}$ to $25 \mathrm{~cm}$ and the third layer is closer to the heating layer under $25 \mathrm{~cm}$ conditions, the temperature rise of the third layer is higher than that of the second layer under $25 \mathrm{~cm}$ conditions. At $15 \mathrm{~cm}$ and $25 \mathrm{~cm}$, the initial temperatures of the fourth layer are $9.05^{\circ} \mathrm{C}$ and $9.15^{\circ} \mathrm{C}$, respectively. After heating for $2 \mathrm{~h}$, the temperatures are 11.45 and $12.28^{\circ} \mathrm{C}$. The temperature rises are $2.4^{\circ} \mathrm{C}$ and $3.13^{\circ} \mathrm{C}$, respectively. With increasing burial depth, the temperature rise of the fourth layer will increase slightly. 
TABLE 6: Temperature rise value of the second, third, and fourth layers under three flow conditions.

\begin{tabular}{lccccc}
\hline Position & $\begin{array}{c}\text { Flow velocity } \\
(\mathrm{m} / \mathrm{s})\end{array}$ & $\begin{array}{c}\text { Initial } \\
\text { temperature }\left({ }^{\circ} \mathrm{C}\right)\end{array}$ & $\begin{array}{c}\text { Temperature after } \\
2 \mathrm{~h}\left({ }^{\circ} \mathrm{C}\right)\end{array}$ & $\begin{array}{c}\text { Temperature after } \\
6 \mathrm{~h}\left({ }^{\circ} \mathrm{C}\right)\end{array}$ & $\begin{array}{c}\text { The temperature rise value between initial } \\
\text { temperature and temperature after } 6 \mathrm{~h}\left({ }^{\circ} \mathrm{C}\right)\end{array}$ \\
\hline \multirow{2}{*}{ The second } & 0.8 & 6.67 & 13.51 & 15.55 & 6.09 \\
layer & 0.85 & 7.43 & 14.76 & 17.23 & 6.5 \\
\hline \multirow{2}{*}{ The third } & 0.9 & 6.49 & 14.67 & 18.03 & 6.03 \\
layer & 0.8 & 7.84 & 10.58 & 13.93 & 6.09 \\
& 0.85 & 8.39 & 11.47 & 14.89 & 6.5 \\
The fourth & 0.9 & 7.76 & 12.12 & 14.79 & \\
layer & 0.8 & 8.78 & 10.48 & & \\
& 0.85 & 9.45 & 10.83 & & \\
\hline
\end{tabular}

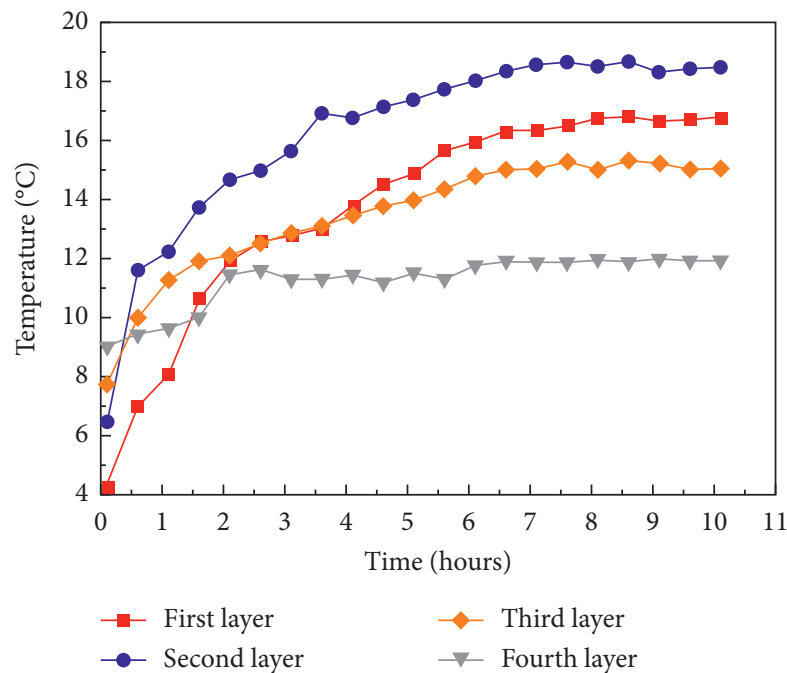

(a)

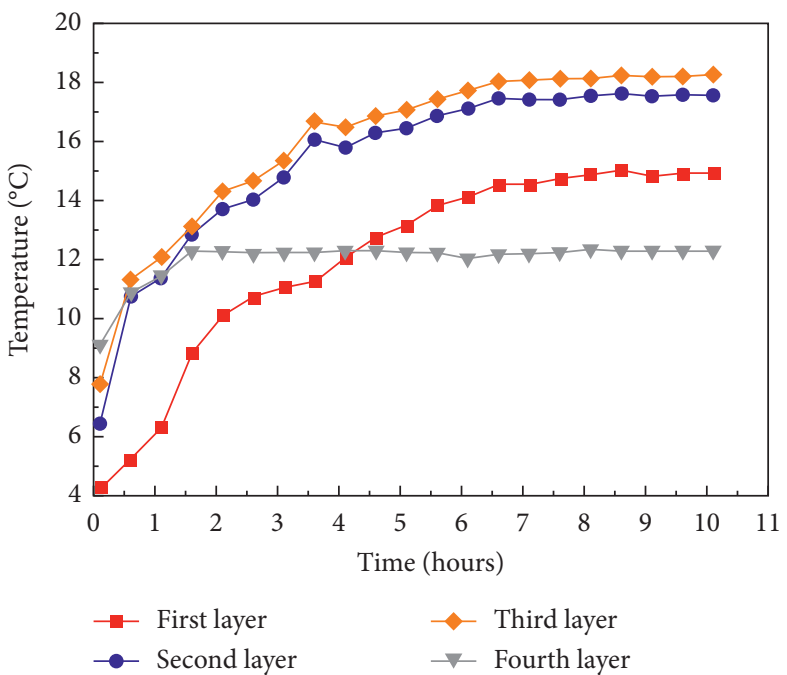

(b)

FIgURE 7: Temperature change curves of the measuring points of four layers under different buried depths: (a) $15 \mathrm{~cm}$; (b) $25 \mathrm{~cm}$.

TABLE 7: Temperature rise value of the first layer under two buried depths.

\begin{tabular}{lcccc}
\hline $\begin{array}{l}\text { Depth } \\
(\mathrm{cm})\end{array}$ & $\begin{array}{c}\text { Initial temperature } \\
\left({ }^{\circ} \mathrm{C}\right)\end{array}$ & $\begin{array}{c}\text { Temperature after } 2 \mathrm{~h} \\
\left({ }^{\circ} \mathrm{C}\right)\end{array}$ & $\begin{array}{c}\text { Temperature after } 6 \mathrm{~h} \\
\left({ }^{\circ} \mathrm{C}\right)\end{array}$ & $\begin{array}{c}\text { The temperature rise value between initial temperature } \\
\text { and temperature after } 6 \mathrm{~h}\left({ }^{\circ} \mathrm{C}\right)\end{array}$ \\
\hline 15 & & 11.97 & 15.97 & 11.66 \\
25 & 4.31 & 10.14 & 14.13 & 9.81 \\
\hline
\end{tabular}

6.3. Temperature Variation and Discussion under Different Space Conditions. Pipeline space is the horizontal distance between two adjacent pipelines, which determines the heat transfer area of the concrete roads. For the same concrete road, a smaller pipeline space indicates more pipes and a larger heat transfer area. With a flow velocity of $0.9 \mathrm{~m} / \mathrm{s}$ and a buried pipe depth of $15 \mathrm{~cm}$, tests under two different space conditions of 10 and $15 \mathrm{~cm}$ were performed.

Figure 8 shows that the average temperature of each measurement point under different space conditions shows an overall upward trend. The first layer temperature variation is shown in Figure 8(a). Before heating, the average initial temperatures of the first layer with pipe spaces of 10 and $15 \mathrm{~cm}$ are 4.31 and $4.18^{\circ} \mathrm{C}$, respectively. After $6 \mathrm{~h}$, the temperature values are stable at $15.97^{\circ} \mathrm{C}$ and $14.46^{\circ} \mathrm{C}$. In the entire temperature rise test, the temperature rises under the two conditions are $11.66^{\circ} \mathrm{C}$ and $10.46^{\circ} \mathrm{C}$. According to Table 9 , when the buried pipe space increases from $10 \mathrm{~cm}$ to $15 \mathrm{~cm}$, the temperature rise decreases by $1.2^{\circ} \mathrm{C}$. Therefore, when the initial velocity is set to $0.9 \mathrm{~km} / \mathrm{h}$ and the geothermal pipe burial depth is set to $15 \mathrm{~cm}$, reducing the buried pipe space could improve the temperature rise of the first layer. After about $1 \mathrm{~h}$, the road temperature is over $8^{\circ} \mathrm{C}$.

Table 10 shows the temperature rise test results of the second, third, and fourth layers under two different space conditions. Figure $8(\mathrm{~b})$ shows the temperature variation of the second layer during the space test. Before heating, the average initial temperatures with pipe spaces of 10 and $15 \mathrm{~cm}$ are $6.49^{\circ} \mathrm{C}$ and $6.58^{\circ} \mathrm{C}$, respectively. After heating for $2 \mathrm{~h}$, the temperatures are $14.67^{\circ} \mathrm{C}$ and $13.19^{\circ} \mathrm{C}$, respectively. After 
TABLE 8: Temperature rise value of the second, third, and fourth layers under two burial depths.

\begin{tabular}{lccccc}
\hline Position & $\begin{array}{c}\text { Depth } \\
(\mathrm{cm})\end{array}$ & $\begin{array}{c}\text { Initial } \\
\text { temperature }\left({ }^{\circ} \mathrm{C}\right)\end{array}$ & $\begin{array}{c}\text { Temperature after } \\
2 \mathrm{~h}\left({ }^{\circ} \mathrm{C}\right)\end{array}$ & $\begin{array}{c}\text { Temperature after } \\
6 \mathrm{~h}\left({ }^{\circ} \mathrm{C}\right)\end{array}$ & $\begin{array}{c}\text { The temperature rise value between initial } \\
\text { temperature and temperature after } 6 \mathrm{~h}\left({ }^{\circ} \mathrm{C}\right)\end{array}$ \\
\hline The second & 15 & 6.49 & 14.67 & 18.03 & 11.54 \\
layer & 25 & 6.47 & 13.72 & 17.11 & 7.64 \\
\hline The third & 15 & 7.76 & 12.12 & 14.79 & 9.52 \\
layer & 25 & 7.81 & 14.33 & 17.73 & \\
\hline The fourth & 15 & 9.05 & 11.45 & & \\
layer & 25 & 9.15 & 12.28 & & \\
\hline
\end{tabular}

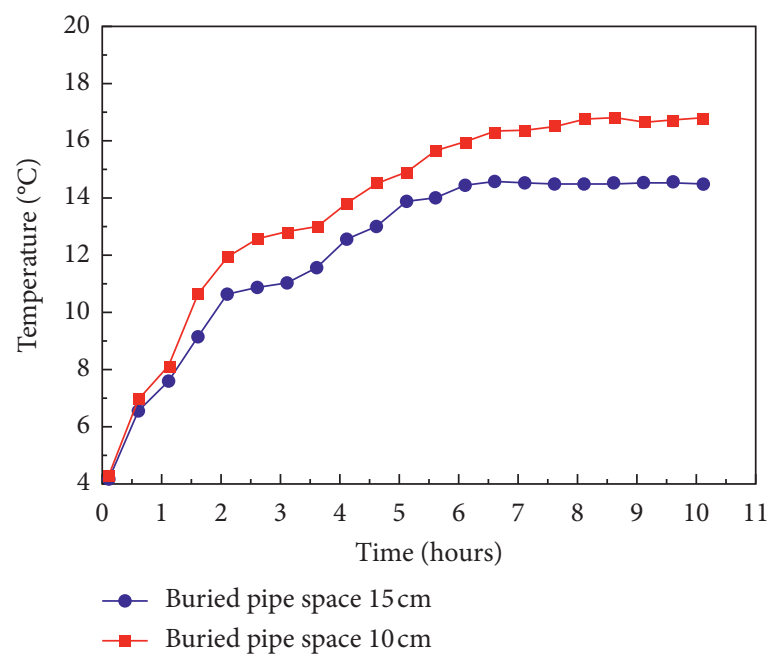

(a)

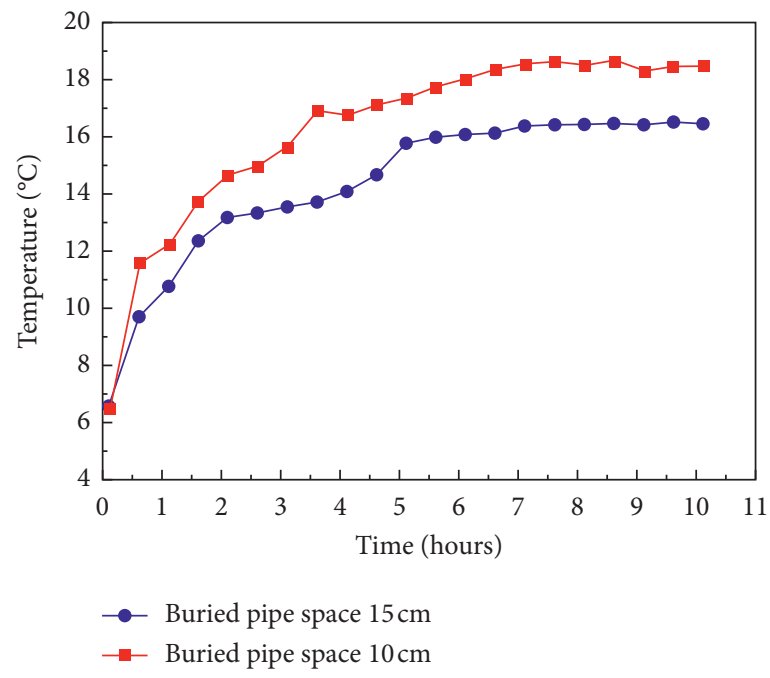

(c)

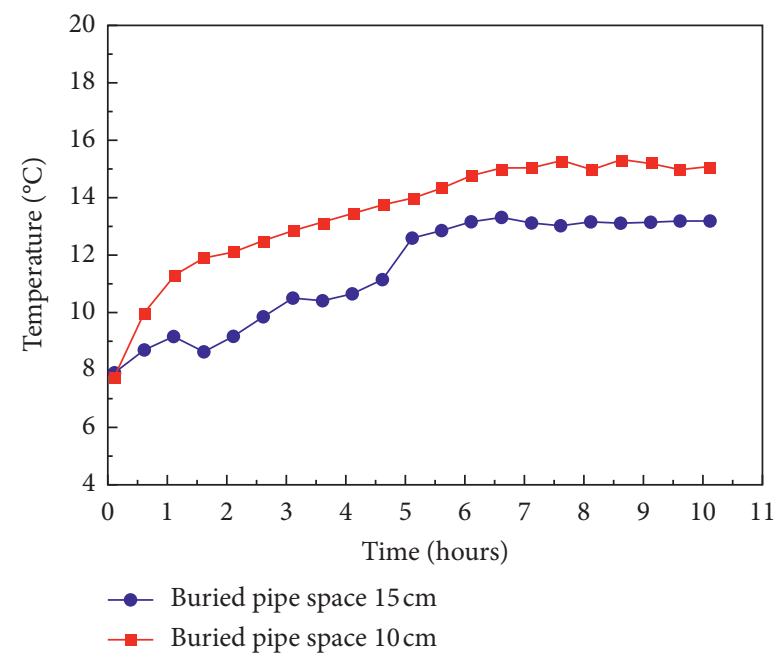

(b)

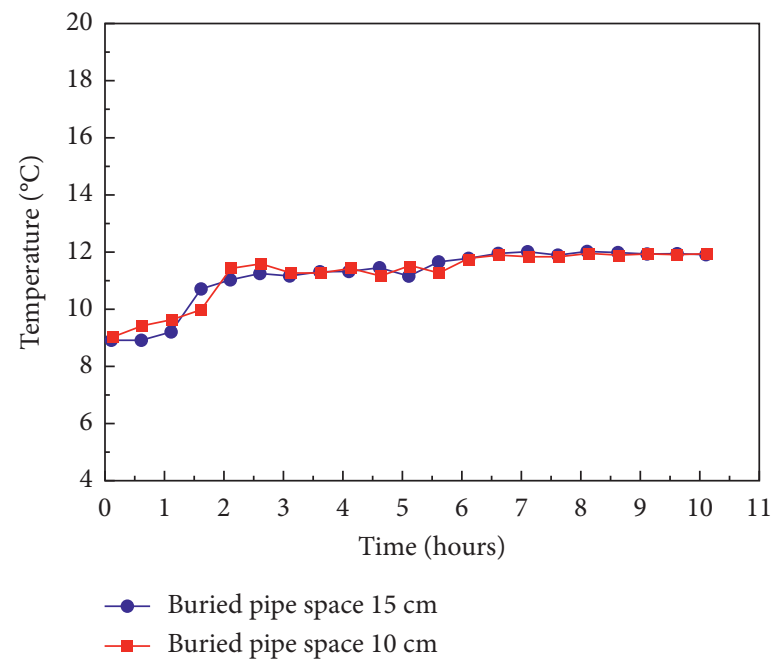

(d)

FIGURE 8: Temperature change curves of the measuring points of each layer under different space conditions: (a) the first layer; (b) the second layer; (c) the third layer; (d) the fourth layer.

heating for $6 \mathrm{~h}$, the temperatures are $18.03^{\circ} \mathrm{C}$ and $16.09^{\circ} \mathrm{C}$, respectively. Compared with the initial temperature, the temperature increases after temperature stabilization are $11.54^{\circ} \mathrm{C}$ and $9.51^{\circ} \mathrm{C}$, respectively. The temperature rise at $10 \mathrm{~cm}$ is $2.03^{\circ} \mathrm{C}$ higher than that at $15 \mathrm{~cm}$. Figure 8 (c) shows the temperature variation of the third layer during the space test. Before heating, the average initial temperatures of the third layer with pipe spaces of 10 and $15 \mathrm{~cm}$ are 7.7 and $7.94^{\circ} \mathrm{C}$, respectively. After heating for $2 \mathrm{~h}$, the temperatures are $12.12^{\circ} \mathrm{C}$ and $9.2^{\circ} \mathrm{C}$, respectively. After heating for $6 \mathrm{~h}$, the 
TABLE 9: Temperature rise value of the first layer under two space conditions.

\begin{tabular}{lcccc}
\hline $\begin{array}{l}\text { Space } \\
(\mathrm{cm})\end{array}$ & $\begin{array}{c}\text { Initial temperature } \\
\left({ }^{\circ} \mathrm{C}\right)\end{array}$ & $\begin{array}{c}\text { Temperature after } 2 \mathrm{~h} \\
\left({ }^{\circ} \mathrm{C}\right)\end{array}$ & $\begin{array}{c}\text { Temperature after } 6 \mathrm{~h} \\
\left({ }^{\circ} \mathrm{C}\right)\end{array}$ & $\begin{array}{c}\text { The temperature rise value between initial temperature and } \\
\text { temperature after } 6 \mathrm{~h}\left({ }^{\circ} \mathrm{C}\right)\end{array}$ \\
\hline 10 & 4.31 & 11.97 & 15.97 & 11.66 \\
15 & 4.18 & 10.64 & 14.46 & 10.46 \\
\hline
\end{tabular}

TABle 10: Temperature rise value of the second, thirds and fourth layers under two different space conditions.

\begin{tabular}{lccccc}
\hline Position & $\begin{array}{c}\text { Space } \\
(\mathrm{cm})\end{array}$ & $\begin{array}{c}\text { Initial } \\
\text { temperature }\left({ }^{\circ} \mathrm{C}\right)\end{array}$ & $\begin{array}{c}\text { Temperature after } \\
2 \mathrm{~h}\left({ }^{\circ} \mathrm{C}\right)\end{array}$ & $\begin{array}{c}\text { Temperature after } \\
6 \mathrm{~h}\left({ }^{\circ} \mathrm{C}\right)\end{array}$ & $\begin{array}{c}\text { The temperature rise value between initial } \\
\text { temperature and temperature after } 6 \mathrm{~h}\left({ }^{\circ} \mathrm{C}\right)\end{array}$ \\
\hline The second & 10 & 6.49 & 14.67 & 18.03 & 11.54 \\
layer & 15 & 6.58 & 13.19 & 16.09 & 9.51 \\
\hline The third & 10 & 7.76 & 12.12 & 14.79 & 5.03 \\
layer & 15 & 7.94 & 9.2 & 13.18 & 5.24 \\
\hline The fourth & 10 & 9.05 & 11.45 & & \\
layer & 15 & 8.93 & 11.05 & & \\
\hline
\end{tabular}

temperatures are $14.79^{\circ} \mathrm{C}$ and $13.18^{\circ} \mathrm{C}$, respectively. Compared with the initial temperature, the temperature increases after temperature stabilization are $7.03^{\circ} \mathrm{C}$ and $5.24^{\circ} \mathrm{C}$, respectively. The temperature rise at $10 \mathrm{~cm}$ is $1.79^{\circ} \mathrm{C}$ higher than that at $15 \mathrm{~cm}$. Figure $8(\mathrm{~d})$ shows the temperature variation of the fourth layer during the space test. Before heating, the average initial temperatures of the fourth layer are 9.05 and $8.93^{\circ} \mathrm{C}$ with pipe spaces of $10 \mathrm{~cm}$ and $15 \mathrm{~cm}$, respectively. After heating for $2 \mathrm{~h}$, the temperatures are $11.45^{\circ} \mathrm{C}$ and $11.05^{\circ} \mathrm{C}$. Compared with the initial temperature, the temperature increases after temperature stabilization are $2.4^{\circ} \mathrm{C}$ and $2.12^{\circ} \mathrm{C}$, respectively.

\section{Conclusion}

Two concrete road models with dimensions of $1 \mathrm{~m} \times 2 \mathrm{~m} \times 0.45 \mathrm{~m}$ were made to study the change rule of road temperature field and observe the relationship between temperature rise and time. The conclusions are given in the following:

(1) Under the set working conditions and according to the measured data, the internal and surface temperatures of the concrete roads model increase, which proves the rationality of the proposed heating method for concrete roads using shallow geothermal energy.

(2) When the buried depth of geothermal pipe is $15 \mathrm{~cm}$ and pipe space is $10 \mathrm{~cm}$, the flow velocity experiments under different working conditions of $0.8 \mathrm{~m} / \mathrm{s}$, $0.85 \mathrm{~m} / \mathrm{s}$, and $0.9 \mathrm{~m} / \mathrm{s}$ show that the temperature rise value at $0.9 \mathrm{~m} / \mathrm{s}$ is $11.66^{\circ} \mathrm{C}$, which is $4.32^{\circ} \mathrm{C}$ and $3.13^{\circ} \mathrm{C}$ higher than that at $0.8 \mathrm{~m} / \mathrm{s}$ and $0.85 \mathrm{~m} / \mathrm{s}$, respectively. Therefore, increasing the initial velocity can improve the temperature rise value of the first layer of the concrete roads.

(3) When the initial velocity is $0.9 \mathrm{~m} / \mathrm{s}$ and the buried pipe space is $10 \mathrm{~cm}$, the buried depth experiments under different working conditions of $15 \mathrm{~cm}$ and $25 \mathrm{~cm}$ show that the first layer temperature rise value at $25 \mathrm{~cm}$ is $9.81^{\circ} \mathrm{C}$, which is $1.85^{\circ} \mathrm{C}$ less than that at $15 \mathrm{~cm}$. Therefore, decreasing the burial depth of the pipes can improve the temperature rise value of the first layer of the concrete roads.

(4) When the initial velocity is $0.9 \mathrm{~m} / \mathrm{s}$ and the buried depth is $15 \mathrm{~cm}$, the buried pipe space experiments under different working conditions of $10 \mathrm{~cm}$ and $15 \mathrm{~cm}$ show that the first layer temperature rise value at $15 \mathrm{~cm}$ is $10.46^{\circ} \mathrm{C}$, which is $1.2^{\circ} \mathrm{C}$ less than that at $10 \mathrm{~cm}$. Therefore, decreasing the burial space of the pipes can improve the temperature rise value of the first layer of the concrete roads.

(5) During the heating process, the temperature of the first layer of the concrete road model can exceed $8^{\circ} \mathrm{C}$ under each working condition within $1.2 \mathrm{~h}$ and become stable after $6 \mathrm{~h}$. Therefore, in practical application, open system $1.5 \mathrm{~h}$ in advance so that it can prevent road snow and freezing. After opening system for $6 \mathrm{~h}$, or stopping snowfall within $6 \mathrm{~h}$, close the system, and the residual temperature stored in the concrete road is used for deicing and snow melting. Under the condition of ensuring that the road surface temperature is above $0^{\circ} \mathrm{C}$, the heating system is turned on intermittently to save energy.

\section{Data Availability}

The data used to support the findings of this study are available from the corresponding author upon request.

\section{Conflicts of Interest}

The authors declare that there are no conflicts of interest regarding the publication of this article.

\section{Acknowledgments}

This research was funded by the Major Technological Innovation Program of Hubei Province (Grant no. 2018AAA028) and the National Natural Science Foundation 
of China (NSFC) (Grant no. 51808203). The authors would like to express their appreciation for the financial assistance from these sources.

\section{References}

[1] H. N. Xu, Y. Q. Tan, C. X. Zhou, and R. Zhang, "Temperature distribution characteristic in solar-ground source coupled snow-melting system for bridge deck," Acta Energiae Solaris Sinica, vol. 33, no. 11, pp. 1920-1925, 2012.

[2] Y. Q. Tan, C. Zhang, H. N. Xu, and D. Tian, "Snow melting and deicing characteristics and pavement performance of active deicing and snow melting pavement," China Journal of Highway Transport, vol. 32, no. 4, pp. 1-17, 2019.

[3] X. B. Li, "The design of turnout snow-removing system for Harbin south marshalling yard," Railway Standard Design, vol. 59, no. 10, pp. 54-60, 2015.

[4] F. Q. Yue, "Research situation and development of highway snow removing and ice melting technology," North Traffic, vol. 5, pp. 62-65, 2014.

[5] C. Z. Jiang, J. Yang, L. Wu et al., "Studies review of organization for winter road maintenance program," Highway, no. 4, pp. 215-219, 2012.

[6] H. L. Dai, K. L. Zhang, X. L. Xu, and H. Y. Yu, "Evaluation on the effects of deicing chemicals on soil and water environment," Procedia Environmental Sciences, vol. 13, pp. 21222130, 2012.

[7] S. M. Green, R. Machin, and M. S. Cresser, "Effect of longterm changes in soil chemistry induced by road salt applications on n-transformations in roadside soils," Environmental Pollution, vol. 152, no. 1, pp. 20-31, 2008.

[8] J. Carmona, P. Garcés, and M. A. Climent, "Efficiency of a conductive cement-based anodic system for the application of cathodic protection, cathodic prevention and electrochemical chloride extraction to control corrosion in reinforced concrete structures," Corrosion Science, vol. 96, pp. 102-111, 2015.

[9] B. D. Lee, Y. S. Choi, Y. G. Kim, I. S. Kim, and E. I. Yang, "A comparison study of performance and environmental impacts of chloride-based deicers and eco-label certified deicers in South Korea," Cold Regions Science and Technology, vol. 143, pp. 43-51, 2017.

[10] N. Aghazadeh, M. Nojavan, and A. A. Mogaddam, "Effects of road-deicing salt $(\mathrm{NaCl})$ and saline water on water quality in the Urmia area, northwest of Iran," Arabian Journal of Geosciences, vol. 5, no. 4, pp. 565-570, 2012.

[11] N. A. Lancaster, J. T. Bushey, C. R. Tobias, B. Song, and T. M. Vadas, "Impact of chloride on denitrification potential in roadside wetlands," Environmental Pollution, vol. 212, pp. 216-223, 2016.

[12] X. Zhang, "Deicing-salt application status and its influence and corresponding countermeasures to the environment," Environmental Sanitation Engineering, vol. 25, no. 5, pp. 64-65, 2017.

[13] C. X. Zhou, Study on Granulated Crumb Rubber Asphalt Mixture Technology in Frost Region, Harbin Institute of Technology, Harbin, China, 2006.

[14] Y. Wang, S. Liu, C. Chen, and B. Zeng, "A hierarchical approach for rain or snow removing in a single color image," IEEE Transactions on Image Processing, vol. 26, no. 8, pp. 3936-3950, 2017.

[15] H. Xu, D. Wang, Y. Tan, J. Zhou, and M. Oeser, "Investigation of design alternatives for hydronic snow melting pavement systems in China," Journal of Cleaner Production, vol. 170, pp. 1413-1422, 2018.
[16] L. Peng, Preparation and Utilize of Snowmelt Admixture for Asphalt Pavement, Chang'an University, Xi'an, China, 2013.

[17] H. Xu and Y. Tan, "Modeling and operation strategy of pavement snow melting systems utilizing low-temperature heating fluids," Energy, vol. 80, pp. 666-676, 2015.

[18] J. Wu, J. Liu, and F. Yang, "Three-phase composite conductive concrete for pavement deicing," Construction and Building Materials, vol. 75, pp. 129-135, 2015.

[19] R. Y. Wang, J. Y. Yu, S. J. Gu, P. He, X. Han, and Q. Liu, "Investigation of migration and self-healing ability of ion chelator in cement based materials by a novel method," Construction and Building Materials, vol. 262, Article ID 120917, 2020.

[20] J. Norambuena-Contreras, L. Poulikakos, H. Baaj, and Q. Liu, "Novel bituminous materials for sustainable pavements," Advances in Materials Science and Engineering, vol. 2020, Article ID 3265052, 2 pages, 2020.

[21] R. Y. Wang, J. Y. Yu, P. He, S. Gu, Z. Cao, and Q. Liu, "Investigation of ion chelator and mineral admixtures improving salt-frost resistance of cement-based materials," Construction and Building Materials, vol. 227, Article ID 116670, 2019.

[22] H. Zhao, Z. Wu, S. Wang, J. Zheng, and G. Che, "Concrete pavement deicing with carbon fiber heating wires," Cold Regions Science and Technology, vol. 65, no. 3, pp. 413-420, 2011.

[23] Y. Tan, Y. T. Zhu, and H. L. Xiao, "Model experimental study of carbon fiber heating wire for deicing and snow melting on a bridge deck," Advances in Civil Engineering, vol. 2020, Article ID 8861468, 15 pages, 2020.

[24] E. Gedik, "Experimental investigation of the thermal performance of a two-phase closed thermosyphon at different operating conditions," Energy and Buildings, vol. 127, pp. 1096-1107, 2016.

[25] M. Mahdavi, S. Tiari, S. De Schampheleire, and S. Qiu, "Experimental study of the thermal characteristics of a heat pipe," Experimental Thermal and Fluid Science, vol. 93, pp. 292-304, 2018.

[26] A. Mauro and J. C. Grossman, "Street-heat: controlling road temperature via low enthalpy geothermal energy," Applied Thermal Engineering, vol. 110, pp. 1653-1658, 2017.

[27] H. N. Xu, Y. Q. Tan, Z. B. Fu, C. Zhou, and R. Zhang, "Study on melting performance in solar-ground source coupled snow-melting system for pavement," Acta Energiae Solaris Sinica, vol. 32, no. 9, pp. 1391-1396, 2011.

[28] H. N. Xu, Y. Q. Tan, and C. X. Zhou, "Simulation analysis of snow melting characteristics of solar-ground source coupled snow-melting system for pavement," Acta Energiae Solaris Sinica, vol. 36, no. 4, pp. 955-962, 2015.

[29] H. J. Wang and J. Zhao, "Experimental study on geothermal ice and snow melting process for roads," Acta Energiae Solaris Sinica, vol. 30, no. 2, pp. 177-181, 2009.

[30] J. Cui, Y. P. Liang, Y. H. Guo, X. B. Zhao, S. Y. Ma, and L. X. Shi, "Numerical study on heat exchange characteristics of runways with snow-melting system using geothermal sources," Applied Mechanics and Materials, vol. 509, pp. 141-146, 2014.

[31] X. Wang, Y. Zhu, M. Zhu, Y. Zhu, H. Fan, and Y. Wang, "Thermal analysis and optimization of an ice and snow melting system using geothermy by super-long flexible heat pipes," Applied Thermal Engineering, vol. 112, pp. 1353-1363, 2017.

[32] B. Zheng, J. L. Zheng, J. Wu, Y. Q. Wei, and Y. W. Li, "Study of temperature characteristics by using pipeline heat source to 
eliminate road surface snow and ice in cold area," Highway, vol. 64, no. 2, pp. 225-232, 2019.

[33] C. Zhang, Y. Q. Tan, F. C. Chen, and Q. Ye, "Long-term thermal analysis of an airfield-runway snow-melting system utilizing heat-pipe technology," Energy Conversion and Management, vol. 186, no. 12, pp. 473-486, 2019.

[34] Q. H. Yin, J. Li, and X. D. Hu, Research on Safety Warning System of Icy Road Base on Multi-Parameters, Wuhan Institute of Technology, Wuhan, China, 2016. 